CANADIAN JOURNAL OF PHILOSOPHY

Supplementary Volume 12

\title{
STEVEN C. PATTEN \\ (1941-1985)
}

Steve Patten was born in 1941. He grew up in a subsidized housing project in Vancouver, Washington; attended art school in San Francisco; received all three degrees in Philosophy from the University of Washington; and assumed his first (and last) teaching position at the University of Lethbridge in 1968. He died in November 1985.

Intellectually as well as physically he was a man of substance. Physically he appeared to have a slightly lower centre of gravity than most people. This was due in part to slightly sloped shoulders and a girth with which he struggled during the last years of his life. So far this might sound like a pear-shaped individual, but he had too much height for that. His height gave him the appearance of solidity and stability.

He had large hands with thick fingers that made the things he handled look more substantial and more valuable than they might be whether it be a cigarette or a piece of sculpture. The way he put a plastic cover on a styrofoam cup of coffee made it look like a delicate container of holy water.

His life was pervaded with quality and substance, from the clothes he wore to the pen he wrote with, from the car he drove to the tires on which it rolled. Like the person, all had a kind of solidity about 
them: a good heft and a stable appearance. But he wasn't an ordinary upper middle class academic, though these observations might suggest it; he never forgot his early life in Vancouver, the tenderloin of San Francisco, or Jackson Street in Seattle. There was quality 'junk' food. He found a kindred soul in Calvin Trillin of The New Yorker magazine who wrote on the best rib joints in North America, the world chili contest and other similar phenomena.

Then there was his kindness. He had the American propensity to root for the underdog. He had a greater than usual sympathy for the South African or inner city blacks, chicanos, native Americans, and the poor. Besides the sympathy, there was almost an envy, not for the condition, but for the vitality that seemed to emerge from the survivors in their art, music, speech, and life style in general. In characteristic self-mocking humor he spoke of changing his name to 'Jesus' ('Hey-soos,' not 'Jesus') or 'Muddy' (after Muddy Waters). He went out of his way to help students who were loners, isolates or were 'sad.'

His life had a theme: life should be lived with intelligence, humor, intensity, and, above all, sensitivity. The intellect of the person who lived it was a very intense and narrowly focused spotlight. What it shined on, he examined in every detail. He turned a thing over and over, on its side, and inside out. And he examined it directly, sideways, and upside down. He stared at it wide-eyed to grasp the whole, and squinted at it in order to discern every detail so that he might properly assess its significance, often as not its significance in the grander scheme of things.

It didn't matter whether it was your face or gait when he first saw you in the morning, Thelonious Monk's Criss Cross, Milgram's experiments on obedience to authority, or the role of religion in history. All were subject to the same scrutiny. The result was, of course, that he often saw things that most people don't see or he saw them in a particularly illuminating way.

I don't intend the spotlight metaphor to mean that his intellect was narrow. It was narrow only in its temporary focus, the concentration of the beam. This gave the intensity that allowed this scrutiny. He shined the beam everywhere: people's appearances, and their lives, music, art, politics, junk food, history, science, and himself. Everything was subjected to the same intense scrutiny, and when he 
exhausted himself on the subject or activity, he moved on.

His career at the University of Lethbridge exhibited this characteristic. He involved himself in university affairs as faculty association president, member of the General Faculties Council ('senate' elsewhere), then almost as quickly as he came upon that scene, he left it, but not before exhausting himself and some of those around him on all the important issues and every aspect of them.

His teaching was similar. He worked hard at lectures and the skills involved, he worked with his students, and occasionally published articles under joint authorship - a phenomenon not all that common at an undergraduate institution. When lecturing he studied the faces of his students to see the slightest evidences of their involvement or lack of involvement - and he was sensitive to every expression of recognition, understanding, agreement, disagreement, as well as to every smile, yawn, or look of disinterestedness. Unequipped with some of the defenses others have, the very act of teaching exacted a terrible price: two-thirds of the way through a semester he would often be exhausted.

His friendships had the same character. They were all-consuming. Again the spotlight: one beam, one object illuminated at a time. One intense friendship with one person at a time. This is a bit of an overstatement, but not by much. One felt the spotlight, one knew that the slightest disagreement or disapproval would be picked up and turned over and over in his mind. There were few secrets from him. He was kind, generous, flattering, sensitive (overly so), demanding, occasionally manipulative, fun and good humored even when he felt terrible.

It is quite understandable that someone who was so sensitive, so perceptive, and so intense in his relationships with others and the world should wonder about his fit with them or it. And so it is not surprising that most of his work was on the self and its relation to the world. His Master's thesis was on one of the more difficult passages in Kierkegaard having to do with self-consciousness; his doctoral dissertation was on Kant and the transcendental deduction which involves the ego in a crucial way.

One can also see his subsequent work in this light: his critique of Hempel's application of the covering law model to explanations by reasons; his critiques of Milgram's experiments on obedience to 
authority; his discussion of deception in experimentation; and his scholarly work on Mill's utilitarianism and Hume's bundle theory of the self.

All of this work is the product of the same focused and intense intellectual labor. On a good day I can last an hour on whether a conclusion follows from some premises; he wanted to talk about it for five or six hours. If the conclusion didn't follow, he wanted to know why the author might have thought it did. Did he or she have a deep insight that was badly expressed? If the conclusion did follow, then he wanted to know why he or anyone else might want to deny that it did. Was there an insight there we might be missing? And when that was done there was the painful question of whether his conclusion on the matter was really worth anything to anyone. This method led to a thoroughness which I hope rubbed off on me. It also led to a strong intolerance and suspicion of glib, facile, quick, or witty philosophical work. Though I haven't read everything he wrote, I think part of this shows through, even though his attractive writing style made it look easy.

I do not believe he would ever have produced a philosophy, a Weltanschauung, had he lived any longer. The mental style I have tried to describe wouldn't make that possible. But we would have had much more sane, solid, and sound philosophical work on a variety of topics. Who knows where else the spotlight might have shone?

During the last years of his life he was concerned with one of the ultimate problems of the relation of the self to the world: the possibility of nuclear omnicide. Seeing that the arms build-up increased the likelihood of omnicide he agonized over the justification for deterrence theory as a justification for that buildup. In our last conversations on this topic, he was wondering what to do with the possibility of nuclear blackmail. I do not know if he came up with an answer. His last published paper on nuclear issues is published here and deals with the individual's role and responsibilities in preventing a nuclear holocaust. It is fitting, therefore, that this volume is dedicated to him.

RONALD M. YOSHIDA

University of Lethbridge 